\title{
Eça de Queirós, Portugal e as relações culturais Eça de Queirós, Portugal e cultural relations
}

\author{
Maria Perla Araújo Morais ${ }^{1}$ \\ Marília Fátima de Oliveira ${ }^{2}$
}

\section{Recebido em: 10/07/2017 \\ Aprovado em: 15/07/2019 Publicado em: 30/07/2019}

RESUMO: Neste texto, apresentaremos como Eça de Queirós discute as relações culturais entre Portugal e outros países europeus, especialmente a França. Acreditamos que, a despeito de uma crítica que procura entender essa discussão do escritor atentando para as relações desvantajosas entre Portugal e outras nações europeias, Eça enfatiza, em algumas obras, o aspecto crítico tanto na reprodução de certas sentimentalidades e costumes, quanto na repulsa dos diálogos culturais. Dessa forma, deixa claro não a questão da pertença cultural, mas da diferença entre culturas, se portando como um mediador que, de maneira consciente e efetiva, promove um debate sobre as relações de poder existentes na Europa do século XIX. Percebemos com Eça de Queirós um projeto de pensar a identidade portuguesa diante da exposição eminente de modos de vida e ideologias de países europeus hegemônicos. Atesta, nesse sentido, o espaço da crise, que será temática de vários escritores finisseculares.

PALAVRAS-CHAVE: Eça de Queirós; França; Sociedade Moderna; Os Maias

\begin{abstract}
In this text, we will present how Eça de Queirós discusses cultural relations between Portugal and other European countries, especially France. We believe that, in spite of a criticism that tries to understand this discussion from the perspective of the disadvantaged relations between Portugal and other European nations, in some of his works Eça emphasizes the critical aspect both in the reproduction of certain sentimentalities and customs, as well as in the repulsion of cultural dialogues. In this way, he clarifies not the question of cultural belonging, but of the difference between cultures, acting as a mediator who, in a conscious and effective way, promotes a debate about the relations of power existing in nineteenth-century Europe. In Eça de Queirós we perceive a project of thinking Portuguese identity before the eminent exposition of ways of life and ideologies of European hegemonic countries. In this sense, he attest a space of crisis, which will be the theme of several finissecular writers
\end{abstract}

KEYWORDS: Eça de Queiros; France; Modern Society; Os Maias

1.Graduação em Letras. Mestrado em Letras. Doutorado em Literatura Comparada. Professora da graduação e do mestrado em Letras da Universidade Federal do Tocantins.ORCID: 0000-00029860-1706 E-mail: perlamorais@gmail.com

2.Graduada com dupla Habilitação (Português/ Inglês). Licenciada em Inglês e Português pela Universidade de São Paulo. Mestre e Doutora em Letras - Literaturas de Língua Inglesa. Professora de Literatura Inglesa na Universidade Federal do Tocantins. ORCID: 0000-0002-8064-1742 E-mail: mariliaoliveira@uft.edu.br 
MORAIS, M.P.A.; OLIVEIRA, M.F.

\section{INTRODUÇÃO}

A presença francesa nas letras, cultura e vida portuguesa é predominante nos séculos XVIII e XIX a ponto de se confundir, em terreno lusitano, a história da França com a história das mentalidades desse período. A França passa a ser referência cultural para uma sociedade ansiosa por uma identificação diferente da que tinha até então: a Espanha. Desde 1640, Portugal rejeita seu iberismo e, paradoxalmente, vê nas outras nações europeias uma oportunidade de afirmar-se enquanto nação.

Jacinto do Prado Coelho chama atenção para a recusa do casticismo em detrimento a um europeísmo como sintoma de modernização e autonomia portuguesas (COELHO, 1992, p. 30). À imagem provinciana e dependente da Espanha, Portugal elegeria para si uma imagem moderna, ao se identificar com a cultura francesa:

(...) a partir do século XVIII a presença da França torna-se hegemônica, e, a bem dizer, a literatura e cultura portuguesa voltam as costas à Espanha; (...) Note-se ainda à margem que, num pequeno país como Portugal, tem havido o compreensível desejo de cultivar as diferenças que justificam a autonomia, e um dos modos de diferenciar da vizinha Espanha - mais propriamente de Castela - foi, no plano cultural, dar primazia à França. (COELHO, 1992, 34)

Almeida Garret e Herculano, sob a ênfase no nacional, não só já identificavam essa presença da França como a criticavam. O certo é que, naquele momento, Portugal demonstra o desejo de ser partícipe de ideias que estão sendo fomentadas pelos países hegemônicos da Europa, como Alemanha, Inglaterra e França.

Queremos entender como essa relação entre Portugal e os demais países europeus, sobretudo a França, se faz presente na obra do escritor português Eça de Queirós. Em vários textos, o escritor nos oferece uma reflexão acalorada sobre essa relação, basta lembrarmos de $A$ correspondência de Fradique Mendes. A obra queirosiana é uma constatação de que os portugueses, no século XIX, ansiavam por uma identificação que chancelasse o sentimento de pertença à modernidade europeia. Ao mesmo tempo, suas narrativas revelam que, quando adaptados ao solo lusitano, muitos dos conceitos modernos deixavam mais à mostra a diferença do que a pertença cultural.

As ideias e orientações sociais do século XIX europeu bem como a inserção desses conceitos em território português serão discutidas em um primeiro momento neste 
MORAIS, M.P.A.; OLIVEIRA, M.F.

texto. Logo em seguida analisaremos como a obra de Eça apresenta a reflexão sobre o lugar português na modernidade europeia e, finalmente, nos centraremos em Os Maias para estudar quais expedientes literários denunciam essa questão no romance.

\section{- PORTUGAL E AS IDEIAS EUROPEIAS: RECEPÇÃo E MEDIAÇÃo}

O Liberalismo francês e o Romantismo francês, inglês e alemão acenavam no século XVIII e XIX como ideias que correspondiam a uma transformação social e cultural, uma espécie de nova organização para novos tempos. A filosofia Liberal, que defendia a liberdade individual nos campos político, econômico e religioso, constituía-se como um conjunto de ideias para as quais parecia difícil se contrapor dadas as promessas de rompimento com antigas estruturas de poder e convite humanista para se adentrar no mundo moderno sob a tutela da originalidade e da autonomia. Essa filosofia estará em afinidade com uma visão do mundo produzida pelos burgueses, classe que ascende vertiginosamente nesse período. Com a Revolução Industrial, a modernidade se consolida, bem como o modo de produção capitalista. Há inúmeras mudanças de ordem científica e, no campo político, começa-se a substituir o Absolutismo por uma visão de Estado burocrático e moderno. Nesse projeto de modernidade, visualizamos alguns pilares, com o da "emancipação", a "esteticização", a "juridificação" e a cientificização da realidade social" (BOAVENTURA, 1999, p.78)

Em termos literários, esses ideais serão movimentados pela estética romântica, que irrompe como resposta às transformações, mas também como elemento formador dessa sociedade moderna:

As artes recebem os novos elementos gerados em tais circunstâncias, incorporando-os em suas várias formas de expressão, já anteriormente preparados com a revolução intelectual dos séculos XVII e XVIII (FALBEL, Nachman. apud GUINSBURG, J. 2008, p.24)

Acontece que esse projeto de Europa liberal não será vivenciado da mesma forma pelos grandes centros econômicos e culturais do século XIX. Além disso, cumpre dizer que a Europa liberal será a mesma que manterá colônias africanas e participará da Conferência de Berlim (1884-1885), que consolidará o neoimperialismo fortalecendo a 
MORAIS, M.P.A.; OLIVEIRA, M.F.

hegemonia de alguns países. Esses fatos, por si só, já mostram o contrassenso do discurso que pregava autonomia e liberdade de antigas estruturas de poder. Revelam que o discurso do desenvolvimento econômico e social será profundamente excludente e seletivo, quando instaura zonas de progressismo e aceita zonas de colonização. Boaventura de Sousa Santos assim discorre sobre as contradições do projeto liberal:

O século XIX, ou seja, o período do capitalismo liberal, é um século fascinante, talvez não tanto quanto o século precedente, mas certamente mais que o século seguinte. O seu fascínio reside em que nele explodem com grande violência as contradições do projeto da modernidade: entre a solidariedade e a identidade, entre a justiça e a autonomia, entre a igualdade e a liberdade. Porque os ideiais se chocam sem mediações, é possível ver nesse período e com igual clareza tanto as tendências para o afunilamento do projecto, como a sua inspiração de globalidade e de frutificação no quotidiano. $O$ afunilamento $e$, portanto, 0 défice de cumprimento está presente, ainda que desigualmente, em cada um dos princípios e lógicas da racionalidade que constituem os pilares da regulação e emancipação. (SANTOS, 1999, p.80)

Quando estudamos as sociedades que se dizem liberais, notamos práticas que questionam esse delineamento político, social e econômico, o que nos faz perceber que certas ideias que estão fomentado a sociedade moderna, como a autonomia e a liberdade, marginalizam amplos contingentes populacionais, dentro e fora dos limites do Estado. Nota-se, então, que essa filosofia pode ser pensada como parte de uma narrativa que justifica e qualifica a ascensão de uma classe econômica, portanto essas ideias são instrumentos de poder dentro das sociedades modernas.

O amplo entendimento sobre o romantismo centra-se na autonomia, na liberdade e, na consequente, originalidade dos escritores em relação aos modelos herdados por uma sociedade cujas transformações sociais não teriam uma profunda ruptura com certas instituições de poder, a saber a monarquia e a religião. Entretanto, também no romantismo há que se questionar o mito da originalidade e autonomia. É o que percebemos no pensamento de René Girard, em Mentira romántica y verdade novelesca. (1985)

O professor João Cezar de Castro Rocha, lendo o filósofo René Girard, explica que pode ser questionada a crença, sobretudo romântica, de que existe um sujeito autocentrado, que se basta a si próprio para determinar sua consciência e o objeto de seu

Revista do SELL (online)2019; 8(1): 164-184 
MORAIS, M.P.A.; OLIVEIRA, M.F.

desejo. Seria isso que Girard entende por mentira romântica:

Românticos e simbolistas querem um desejo transfigurador, mas o querem perfeitamente espontâneo. Não gostam de ouvir falar do Outro'. (GIRARD, 1985, p.41, tradução nossa)

Para Girard, o homem moderno está desesperadamente "apaixonado" pela "ilusão da autonomia" e ideia do "desejo espontâneo" (GIRARD, 1985, p.21). A essa ideia, João Cezar contrapõe o conceito giradiano de verdade romanesca, que destaca a importância que o outro tem para mediar a constituição do eu, principalmente, para a definição do objeto do seu desejo. Sabendo da centralidade que a figura do desejo tem para o homem, o que estaria acontecendo nos romances da tradição ocidental seria a supressão ou não da figura do mediador cultural, esse outro fundamental para o eu. (ROCHA, 2017)

Persistir na mentira romântica do mito da originalidade seria entender os romances dessa tradição literária sobre o aspecto da diferença, quando o que se sobressai é a semelhança, no que diz respeito à questão do desejo. A essa mentira romântica se contrapõe a verdade romanesca presente em obras que deixam claro a figura não do artista gênio original, mas dele como mediador cultural.

Os romancistas que ocultam, consciente ou inconscientemente, a presença do mediador promovem a mentira romântica, segundo a qual os sujeitos se relacionam espontânea e diretamente. Por sua vez, os escritores que tematizam a relevância do mediador permitem que se vislumbre a verdade romanesca, segundo a qual os sujeitos desejam por meio da imitação de modelos, ainda que ignorem o movimento que os dirige. (ROCHA, 2017, p.109-110)

Em sociedades como a portuguesa, a partir da figura do escritor Eça de Queirós como mediador cultural, percebemos como o desejo de modernidade passa a ser um desejo impulsionado pelo outro, que nesse momento são os países europeus hegemônicos. Os romances de Eça tematizam essa triangulação entre um eu, um outro e o desejo, acabando por demonstrar as transformações a que sistemas de sentido estarão expostas no ambiente cultural português.

1 "Románticos y simbolistas quieren um deseo transfigurador, pero lo quieren perfectament espontâneo. No les gusta oír hablar del Outro". 
MORAIS, M.P.A.; OLIVEIRA, M.F.

Boaventura de Sousa Santos desenvolve o argumento de que Portugal possui uma cultura de fronteira, aquela cuja homogeneidade interna não é promovida por um Estado, tampouco a diferenciação de culturas exteriores:

(...) enquanto identidade nacional Portugal nunca foi semelhante às identificações culturais positivas que eram as culturas europeias, nem foi nunca semelhante às identificações culturais negativas que eram, desde o século XV, os outros, os não europeus. A manifestação paradigmática desta matriz intermédia, semiperiférica, da cultura portuguesa está no facto de os Portugueses terem sido, a partir do século XVII (...), o único povo europeu que, ao mesmo tempo que observava e considerava os povos das suas colónias como primitivos e selvagens, era, ele próprio, observado e considerado, por viajantes estudiosos dos países centrais da Europa do Norte, como primitivo e selvagem (SANTOS, 1999, p.133)

Pensemos numa questão apenas, a econômica. Em Portugal ela, no século XIX, era ditada majoritariamente pelo Estado e não por uma burguesia em ascensão. Vemos, portanto, claramente, uma vivência do Liberalismo de maneira singular. Passados os primeiros anos do século XIX em que a família real se muda para o Brasil e Napoleão invade o território português, temos no ano de 1821 o regresso de D. João VI para uma sociedade dividida: uns mais progressistas e liberais; outros queriam a permanência da Corte tradicional. Provavelmente, a independência do Brasil foi um grande golpe até para - liberalismo português, a despeito de uma defesa da liberdade em sentido amplo pretensamente defendida por essa filosofia. Nesse contexto, o absolutismo moderado de D. João VI perde o prestígio e ganha força em Portugal outro mais radical, representado por Carlota Joaquina e seu filho D. Miguel. Durante esse século, serão revoltas, motins que nos mostrarão uma sociedade civil com ideologia e constituição bem singulares:

Esses movimentos político-militares são similares ideologicamente à revolução de 1848 na França: têm um caráter pequeno-burguês e servem de válvula de escape para os grupos sociais frustrados com os rumos tomados pela revolução burguesa. Mas as condições eram diferentes nos dois países: se na França o movimento teve suas bases no desenvolvimento industrial, em Portugal apenas reflete a crise no setor agrário de um país dependente, em especial, da Inglaterra. (ABDALA JÜNIOR e PASCHOALIN, 1994, p.98)

Devido ao inexpressivo desenvolvimento industrial português, a sociedade burguesa não será responsável por uma mudança drástica no regime político baseado no 
MORAIS, M.P.A.; OLIVEIRA, M.F.

Absolutismo. Mas França e Inglaterra se constituem em países que, pela força hegemônica, acabam fornecendo, para aqueles que reproduzem seus hábitos, costumes e ideologias, um sentimento de distinção:

Portugal não está ainda na Europa, mesmo se a nova Europa da máquina de vapor e do telégrafo, da maior circulação dos jornais, está já dentro das suas fronteiras. Na década de 60, Paris, então capital cultural da Europa, fica ligada a Lisboa. Em sentido próprio, Portugal acede um pouco ao coração da Europa. Portugal, isto é, a sua escassa classe financeira, industrial, aristocrática e política, mas também de maneira paradoxal, a sua classe intelectual. É nesse momento exacto que uma nova geração, como se acabasse de descobrir um tesouro caído do céu, descobre que não é europeia, isto é, que não sente, nem conhece, nem pensa, nem cria como podia fazê-lo se estivesse "realmente" nessa Europa que Ihe envia as criações e os ecos reais ou fantásticos do que toda uma juventude vai nomear a "vida superior", a da Civilização, com maiúscula. (LOURENÇO, 2012, p.36)

Dado o poder hegemônico desses países, os paradigmas que elegem se tornam em fórmula que todos querem repetir, no sentido, apenas, de pertença ao mundo que representam, sem necessariamente pensarem na questão de como isso será feito dado o contexto diferente. O mediador cultural é o que está atento ao trânsito, às dinâmicas de imposições e sobreposições culturais. Nesse sentido, podemos ver nos romances de Eça de Queirós algo que Santos discorre sobre a classe burguesa representada no Realismo:

(...) uma classe, a burguesia, que desperdiça o potencial de se transformar numa classe universal, capaz de transformar globalmente a sociedade, um pouco à maneira da classe universal de Hegel, a burocracia, ou da classe universal de Marx, a classe operária, (SANTOS, 1999, p.83)

Eça de Queirós apresenta essa burguesia que circula pelos bens culturais assumindo-os como luxo e não como possibilidade de transformação social. Se esse questionamento já está posto nos países europeus hegemônicos, na sociedade portuguesa tal constatação vem acrescida de uma profunda melancolia e tédio por parte dos personagens.

A literatura portuguesa do século XIX desse período atesta a relação de atração ou repulsão de Portugal com outras nações europeias. A obra de Eça de Queirós, por exemplo, desenvolve uma visão bastante peculiar a respeito dessa questão, principalmente nos últimos textos. Delimitar e discutir essa relação entre culturas 
MORAIS, M.P.A.; OLIVEIRA, M.F.

hegemônicas e uma cultura vista como semiperiférica ${ }^{2}$ dentro da Europa era tão urgente que Eça de Queirós dedicou dois textos bastante explícitos sobre esse assunto: $A$ Inglaterra e a França julgadas por um inglês (1884) e O Francesismo (1887). Em A correspondência de Fradique Mendes, encontramos a célebre frase, que será repetida em O Francesismo: "Lisboa é uma cidade traduzida do francês em calão" (QUEIRÓS, 2013, p. 74). Seu período como diplomata na Inglaterra (1874-78) favoreceu o contato com a literatura e cultura britânicas. Longe de apenas propiciar uma visão crítica de Portugal, tal afastamento pode ter possibilitado entender as diferenças culturais de maneira mais efetiva e produtiva.

Portanto, tanto em relação ao liberalismo quanto ao romantismo, é possível produzir narrativas que os questionam, principalmente no que concerne ao mito das saídas originais e autônomas dos sujeitos. Ambos são sistemas assentados em concepções que defendem um ponto de vista claramente atrelado aos jogos de poderes que ajudam na reconfiguração do mundo no século XIX.

\section{- EÇA DE QUEIRÓS E O ESPAÇO DA CULTURA PORTUGUESA}

Eça de Queirós é, muitas vezes, acusado de afrancesado, por sua defesa de uma modernização portuguesa aos moldes dos franceses. Basta vermos seu posicionamento nas Conferências do Cassino, em que defende uma literatura totalmente em sintonia com o projeto Realista francês. Antonio Candido atesta esse momento, visualizando na obra duas temáticas distintas: a urbana, centrada na modernidade aos moldes franceses, e outra rural, caracterizada por um provincialismo e tradicionalismo. Em ambas, percebe-se o mesmo tratamento da matéria social, vista sempre a partir da crítica:

Nos primeiros livros sentimos predominar a visão urbana da vida, mesmo quando o tema é rural ou semi-rural. O jovem Eça, socialista, nutrido de cultura francesa, concebia a sociedade como organismo em progresso constante, impelido pela técnica industrial sob o signo da concorrência econômica. O que via na pátria, todavia, era uma civilização pachorrenta,

2 De acordo com Boaventura de Sousa Santos, a sociedade portuguesa é "semiperiférica", "dependente". 
MORAIS, M.P.A.; OLIVEIRA, M.F.

baseada na agricultura e no comércio, quase inteiramente à margem da vida febril do Ocidente (...) O jovem bacharel socialista odiava a estagnação do país, os costumes conservadores e os grupos que os representavam. Clero, aristocracia, burguesia, tudo lhe despertava inclinação combativa. (CANDIDO, 2006, p. 39)

Analisar as obras de Eça de Queirós como um simples receptáculo das influências da sociedade francesa não se sustenta. Até porque dentro da área da Literatura Comparada esse tipo de estudo mostrou-se muito compatível com um projeto de cunho imperialista, ao estabelecer hierarquias entre influenciados e fontes. Contra isso, muitos textos do escritor português se constituem numa visão crítica sobre a forma como Portugal se relaciona com outras nações europeias, basta vermos o retrato de alguns estrangeirados nos seus romances. Travestidos de europeus, menosprezam Portugal, identificando em outras nações características como modernização, civilidade e cultura:

Nos seus romances, Eça de Queirós mete com razão a ridículo não só a auto-suficiência dos que, tal o conde de Ribamar no O Crime do Padre Amaro afirmam com uma petulância idiota que seu país causa inveja ao mundo inteiro, mas ainda o esnobismo igualmente fútil dos que, a exemplo do Visconde Reinaldo no O Primo Basílio, se distraem a dizer mal do que é português e afirmam que só podem já viver num meio civilizado como Paris. (COELHO, 1992, p. 33)

Tal qual a figura do mediador cultural, Eça desnuda as relações culturais com países hegemônicos, oferecendo um texto crítico e consciente dos jogos de poder oriundos desses diálogos. Antonio Candido enumera vários personagens esnobes que querem seguir padrões modernos da "civilização arejada" tanto francesa quanto inglesa, mas acabam por se tornar produtos "híbridos, estéreis, desfibrilados", pois não conseguem se portar com originalidade na vida ou no pensamento. (CANDIDO, 2006, p. 43)

À imagem esnobe, a literatura de Eça de Queirós nos oferece um bom exemplo de como dialogar de forma produtiva com outras culturas. Eça foi acusado de plágio de romances franceses em O Crime do Padre Amaro e em O Primo Basílio. Paradoxalmente, foi essa arte de países estrangeiros que possibilitou a Eça de Queirós fazer uma caricatura de Portugal:

(...) ao mesmo tempo que o inspirava, através dos mestres que Eça 
MORAIS, M.P.A.; OLIVEIRA, M.F.

sempre reconheceu serem os seus (...), essa mesma França fornecia a matéria necessária à desconstrução da sua própria influência, sobretudo ao nível do imaginário desdobrado em imagens plurais: a condição feminina, alimentando a sua fragilidade psicológica em leituras romanescas, predominantemente francesas, que the falseiam a realidade; o aprendiz de escritor, inexperiente e ingênuo, que confunde a realidade de Lisboa com a sociedade parisiense desenhada por Balzac; o novo-rico que ostenta seu conhecimento de Paris e dos romances de Daudet como sinal supremo de "chic"; a sociedade culta, mas nem por isso menos colonizada pelos hábitos franceses (DUARTE, 2008, p. 68).

A despeito da crítica da "influência", é interessante constatar o diálogo o escritor português promove com outros sistemas literários, respondendo de maneira efetiva a modelos de sentimentalidade e modernidade dos outros países europeus. Para o crítico brasileiro Silviano Santiago, os romances de Eça não são uma apologia ao realismo francês. Pelo contrário, são uma forma de enriquecer o modelo romanesco recebido. Santiago percebe em Eça de Queirós não as propostas defendidas nas Conferências do Cassino, mas sim como o escritor português se apropriava do realismo em uma realidade diversa à francesa (SANTIAGO, 2000). Também a discussão sobre literatura parece seguir esse viés. Nesse sentido, lembremos, mais uma vez, de O Primo Basílio, em que vemos bem clara a postura que Eça defendera na sua palestra "A Literatura Nova ou $O$ realismo como nova expressão de arte", proferida nas Conferências do Cassino em 12 de junho de 1871. A própria história do romance contrapõe-se à história que se cria dentro do texto: uma peça teatral chamada "Honra e Paixão", de Ernestinho Ledesma. Os personagens do romance discutem essa peça teatral que trata de um caso extraconjugal e o destino da mulher que trai o marido. O empresário de Ledesma, para agradar o gosto melodramático do público português, quer que a heroína não morra no final da peça e o marido lhe perdoe. Eça responde a essas orientações com a própria feitura do romance $O$ Primo Basílio.

Para Silviano Santiago, essa simbiose do texto com o intertexto é um dos grandes expedientes literários do romance. É mesmo a diferença que enriquece os textos realistas: “(...) este talvez seja o fado e a originalidade das melhores obras escritas nas culturas dependentes de outra cultura: a meditação sobre a obra anterior conduz o artista à transgressão ao modelo" (SANTIAGO, 2000, p.63).

Em O Primo Basílio, personagens como Luísa e Basílio evidenciam essa recepção

Revista do SELL (online)2019; 8(1): 164-184 
MORAIS, M.P.A.; OLIVEIRA, M.F.

das ideias francesas e inglesas. Em ambos, a recepção é vista como uma sobrevalorização dessas culturas, por isso não é raro a explicitação de um tédio e de um desprezo pela vida portuguesa. Luísa busca nos romances românticos ingleses e franceses alívio para uma monotonia e provincialismo lusitanos:

Luísa espreguiçou-se. Que seca ter de ir vestir! (..) Tornou-se a espreguiçar-se. E saltando na ponta do pé descalço, foi buscar ao aparador por detrás de uma composta um livro um pouco enxovalhado.

(...) Em dezoito anos entusiasmara-se por Walter Scott e pela Escócia (...) Mas agora era o moderno que a cativava: Paris, as suas mobílias, as suas sentimentalidades. Ria-se dos trovadores, exaltara-se por Mr. de Camors; e os homens ideais apareciam-lhe de gravata branca, nas ombreiras das salas de baile, com um magnetismo no olhar, devorados de paixão, tendo palavras sublimes (...) (QUEIRÓS, 1994, p. 5-6)

Eça, quando apresenta Luísa fazendo essas leituras de romances famosos da época, desfere sua crítica ao romantismo. Paris seduz Luísa pelo modelo de sentimentalidade e pela moda. De fato, ao longo do romance, o narrador quer nos convencer de que Luísa é refém dos episódios românticos que lê e que aspira viver e também, no mesmo nível, de um excesso de preocupação com vestidos, chapéus, luvas e apetrechos. Ou seja, Luísa não estabelece, de acordo com o narrador, distinção quanto aos objetos de seu desejo. Quanto a essa vulnerabilidade aos desejos, não podemos esquecer de que essa personagem também conta a história da mulher no século XIX. Retratá-la a essa exposição em demasia também diz respeito a uma narrativa que justifica esse excesso ratificando a leitura sobre a mulher na sociedade.

Basílio também é seduzido pela moda parisiense. Em seu encontro com Luísa, diz que trouxera da capital francesa um presente para a prima e menospreza o estilo de roupa lusitano:

-E qual outro presente, então, além do rosário?

- Ah! Luvas. Luvas de verão, de peau de suède, de oito botões. Luvas decentes. Vocês aqui usam umas luvitas de dois botões, a ver-se o punho, um horror!.

De resto pelo que tinha visto, as mulheres em Lisboa cada dia se vestiam pior! Era atroz! Não dizia por ela; até aquele vestido chique, era simples, era honesto. Mas em geral era um horror. Em Paris! Que deliciosas, que frescas as toaletes daquele verão! Oh! Mas em Paris!...Tudo é superior! 
MORAIS, M.P.A.; OLIVEIRA, M.F.

Por exemplo, desde que chegara ainda não pudera comer. Positivamente não podia comer! - Só em Paris se come - resumiu (QUEIRÓS, 1994, p. 38).

Percebe-se pelos suspiros de ambos as promessas de felicidade proporcionada pelo belo, como discute Baudelaire em Sobre a Modernidade (BAUDELAIRE, 1996, p. 9). Como promessa e não como felicidade, os personagens acumulam, além de toaletes, esnobismo e tédio. Fora todas as implicações de consumo que esse fato implica, vemos bem claramente nesses dois personagens uma crítica a uma maneira esnobe, um sonho bem subjetivo de viver os novos tempos, representado aqui pela moda e pelos costumes franceses. Tais mudanças são lidas no espaço português como um símbolo de distinção, como luxo cultural do estrangeirado Basílio e da burguesa Luísa.

Os bens da cultura francesa tornam-se um sonho subjetivo de, ao tomar posse desses objetos, desses costumes e hábitos, haja uma pertença cultural, esquecendo qualquer utopia quanto à transformação social a partir da sociedade de consumo e capitalismo.

\section{- OS MAIAS E A DIFERENÇA CULTURAL PORTUGUESA}

Também há, em Os Maias, uma ânsia de civilização, vivida como uma espécie de luxo, capricho cultural. Como luxo e não como bem cultural comum a todos, a modernidade serviria para distinguir, ou seja, junto com o dinheiro, a posição, esse capricho seria mais um expediente de diferença social:

O traço dominante de todo este mundo social lisboeta é a sua ânsia de acesso à civilização, ou de a reproduzir como um luxo cultural: isso sentese nas próprias figuras centrais do Ramalhete, e da Toca, que são particularmente anglómanas. João da Ega, "o grande fraseador", amigo íntimo de Carlos Eduardo, que os Maias tratam por "John", e que às vezes parece uma autocaricatura de Eça, exprime tal mania de fazer civilização de modo excêntrico e volúvel, hiberbolizando do fundo alguns dos ideiais sucessivos ou alternativas da geração de 71 ; e as feições mais grosseiras dessa mania tão típica encarna num dos mais prodigiosos tipos queirosianos, Dâmaso Salcede. (SARAIVA e LOPES, 1996, p. 876) 
MORAIS, M.P.A.; OLIVEIRA, M.F.

Se em outros romances Eça de Queirós já tinha se dedicado ao entendimento do impacto dessa vivência do luxo sob o mundo pequeno burguês, aqui ele perscruta a alta burguesia e aristocracia. Nesse sentido, Os Maias, cujo título soa um tanto anacrônico por evocar um tempo de famílias, de tradições, heranças, um modelo de ligações sociais avesso ao mundo burguês, conjuga-se com uma percepção deturpada da modernidade. Além disso, o título é afrancesado, o que não deixa de soar como uma ironia à maneira portuguesa de viver uma outra cultura e ainda como um desgosto com a França (MEDINA, 1992, p. 34).

Atentemos, em Os Maias, para a cena inicial da apresentação do Ramalhete. O personagem Afonso da Maia aparece no terraço da casa observando o espetáculo ao seu redor. Acreditamos que há nesse procedimento queirosiano uma tentativa de que captemos o olhar de Afonso, o olhar de um patriarca, diante de um mundo em mudança. O que ele constata é a modernização da cidade, que lhe impede a vista do mar. Esse dado é visto com um certo desalento por Afonso:

O que desconsolara Afonso, ao princípio, fora a vista do terraço - de onde outrora, de certo, se abrangia até ao mar. Mas as casas edificadas em redor no último anos, tinham tapado o horizonte esplêndido (...) E sempre ao fundo o pedaço de monte verde-negro, com um moinho parado no alto e duas casas brancas ao rés da água, cheias de expressão - ora faiscantes e despedindo raios das vidraças acesas em brasa; ora tomando aos fins da tarde um ar pensativo, cobertas dos rosados tenros do poente (...); e de uma tristeza arrepiada nos dias de chuva, tão sós, tão brancas, como nuas, sob o tempo agreste (QUEIRÓS, 2000, p. 22-3).

Os Maias é um grande estudo sobre a modernidade em Portugal, sob o ponto de vista da alta burguesia e aristocracia. Essa modernidade vai apresentar seus dramas para ser operacionalizada em Portugal.

Pensemos, por exemplo, na Lisboa descrita em O Primo Basílio. Se a organização urbana do século XIX encurralava o povo nas periferias e cortiços ao redor da cidade, era em respeito ao sonho asséptico burguês e ao seu medo de que essa parcela da população impedisse o progresso e a tranquilidade. Já os burgueses lisboetas experimentavam o mal-estar urbano por outros expedientes, como o calor excessivo, o excesso de doenças e decrepitude: 
Mas é uma Lisboa que não é Paris que Eça de Queirós recompõe em $O$ Primo Basílio, uma cidade que, longe de ser um grande centro, é povoada por casas e por paisagens preenchidas por um cotidiano repleto de provincialismo. Se o mal-estar citadino é gerado pelo excesso dentro de núcleos urbanos como Paris, no caso português é a precariedade, ou melhor, o excesso da falta que gera o incômodo na experiência urbana. Uma cidade abafada pelo calor, castigada pelo sol, assustada pela ameaça da decrepitude, invadida pela pobreza e contaminada por vícios e por doenças é a que Eça de Queirós recria (...) (FIGUEIREDO, 2001, p. 316-7).

Eça de Queirós trata desses dramas, dessa pretensa incompatibilidade entre o que se respirava na grande Europa e o que acontecia em Portugal, ou seja, entre o que se idealizava dos grandes centros hegemônicos europeus e de sua semiperiferia. Mas, quando o faz, não quer ensinar uma lição de como ser um francês. Pelo contrário, quer discutir uma nação em que não há espaço para o velho e o novo ora não tem credibilidade alguma, ora é abraçado como sinônimo de distinção. Esse não-lugar português dentro da modernidade é o ponto nodal de várias passagens dos textos queirosianos.

Vejamos em Os Maias o percurso de um personagem que cria muita empatia no romance, Afonso da Maia. Sua trajetória é peculiar porque, quando jovem, simpatizara-se com os ideais liberais. A descrição de Afonso nessa época é interessante:

O antepassado cujos olhos se enchiam agora de uma luz de ternuras (...) fora na opinião de seu pai, algum tempo, o mais feroz jacobino de Portugal! E todavia, o furor revolucionário do pobre moço consistira em ler Rousseau, Volney, Helvécio, e a Enciclopédia; em atirar foguetes de lágrimas à Constituição; e ir de chapéu à liberal e alta gravata azul, recitando pelas lojas maçônicas odes abomináveis ao Supremo Arquiteto do Universo. (QUEIRÓS, 2000, p. 24)

Atitudes como essas, mesmo que não tão revolucionárias, eram lidas pelo conservadorismo e catolicismo do pai de Afonso como uma afronta. Para o ambiente resistente à mudança social, bastava isso para que qualquer um fosse apelidado de jacobino, Marat. Até mesmo palavras tão caras ao liberalismo eram lidas como xingamento no ambiente do conservadorismo português: "Ao princípio, na esperança que o menino se emendasse, contentou-se em lhe mostrar um carão severo e chamar-lhe com sarcasmo - Cidadão!" (QUEIROS, 2000, p. 25) Eça reflete sobre a recepção 
MORAIS, M.P.A.; OLIVEIRA, M.F.

problemática do discurso liberal em solo português. O desfecho da orientação juvenil de Afonso da Maia não poderia ser mais irônico:

Durante os dias da Abrilada estava ele nas corridas de Epsom, no alto de uma sege de posta, com um grande nariz postiço, dando hurras medonhos - bem diferente dos seus irmãos de maçonaria, que a essas horas o senhor Infante espicaçava o chuço, pelas vielas do Bairro Alto, no seu rijo cavalo de Alter. (QUEIRÓS, 2000, p. 26)

Poderíamos discutir esse desfecho levando em conta um possível aspecto volúvel do jovem Afonso. Entretanto, porque recorrente em muitos personagens, essa tendência a se empolgar com uma ideia e abandoná-la em seguida (ou, como diria o narrador, "tudo" ser "tão ligeiro e vago como o fumo") não deixa de sugerir a maneira "apressada" com que os portugueses se relacionam com os conceitos e ideias franceses e principalmente os aristocratas, para os quais a revolução provavelmente não teria nenhum sentido, a não ser a de um disparate juvenil. Eça de Queirós nos fala abertamente sobre esse aspecto, a partir do personagem Ega:

-Enfim - exclamou Ega - se não aparecerem mulheres, importam-se, que é em Portugal para onde tudo o recurso natural. Aqui importa-se tudo. Leis, ideias, filosofias, teorias, assuntos, estéticas, ciências, estilo, indústrias, modas, maneiras, pilhérias, tudo nos vem em caixotes pelo paquete. A civilização custa-nos caríssima, com os direitos da alfândega; e é em segunda mão, não foi feita para nós, fica-nos curta nas mangas. (QUEIRÓS, 2000, p. 116)

Ega discute aqui como os sistemas de sentido dos grandes centros europeus são vistos por Portugal como garantia de acesso à civilização, mas, ao se chocarem com um espaço diverso, deixam mais nítidas as contradições da nação, ou seja, evidencia-se não a pertença, mas a diferença cultural.

Essa diferença aparece trabalhada em vários momentos do romance. Seja quando Carlos da Maia confessa ao avô que é um ser inferior, porque prefere a sonoridade de um adjetivo à exatidão de um sistema, prefere a retórica à ideia; seja quando Ega, para estar na moda, veste-se com uma roupa totalmente inadequada para o clima português; seja quando vemos as ambições vagas e itinerantes de Carlos da Maia com relação ao seu trabalho, dada sua condição abastada. A inadequação da palavra "trabalho" a Carlos da 
MORAIS, M.P.A.; OLIVEIRA, M.F.

Maia é visível ao longo do romance.

Enquanto países como a França já discutiam se a burguesia teria traído a revolução liberal porque, acabado o Antigo Regime, essa classe teria se identificado com os papeis sociais da aristocracia e não com o povo, em Os Maias esse ambiente não está posto, dada a permanência conturbada da monarquia e seu aparato. É o que revela, por exemplo, esse questionamento de trabalho em Carlos da Maia.

Eça, portanto, discute como as margens dos grandes centros econômicos e culturais da Europa, aqui no caso Portugal, estariam traduzindo o fluxo de ideias dos países hegemônicos. Nesse sentido, é sintomático o final de Os Maias, em que se agrega a essa discussão um questionamento maior dos próprios rumos da Europa sob os moldes de um Positivismo:

Não se esqueça que a evolução literária queirosiana não constitui, na década que vai de 1880 a 1890, um processo isolado; ela inscreve-se na crise de confiança que atinge a cosmovisão naturalista e, de um modo geral, a crença na suposta coesão dos valores do Positivismo. É essa crise de confiança que irremediavelmente se instala quando, quase no final d'Os Maias, João da Ega descobre perplexo que, apesar de viver "numa sociedade burguesa, bem policiada, bem escriturada, garantida por tantas lei, documentada por tantos papeis, com tanto registro de baptismo, com tanta certidão de casamento", Carlos da Maia não escapa do absurdo implacável de um incesto trágico. (REIS, 1999, p. 150)

Em Os Maias, ainda encena-se essa questão por um expediente intertextual, tal qual "Honra e Paixão", a peça que Ernestinho Ledesma escreve em O Primo Basílio. Trata-se da obra que Ega estaria escrevendo, Memórias dum Átomo. Aliás esse texto é um projeto a que Eça de Queirós se refere mais de uma vez em sua obra. O texto seria uma espécie de epopeia em prosa, uma Bíblia da nova Humanidade, capitaneada por Ega, a ciência e a razão esclarecida. Ega nas Memórias iria revisitar, na forma de um átomo, todos os episódios da humanidade:

Este átomo (o átomo Ega, como se Ihe chamava a sério, em Coimbra), aparecia no primeiro capítulo, rolando ainda no vago das nebulosas primitivas: depois vinha embrulhado, faísca candente na massa de fogo que devia ser mais tarde a Terra; enfim, fazia parte da primeira folha de planta que surgiu da crosta ainda mole do globo. Desde então, viajando nas incessantes transformações da substância, o átomo Ega entrava na rude estrutura do Orango, pai da humanidade - e mais tarde vivia nos 
MORAIS, M.P.A.; OLIVEIRA, M.F.

lábios de Platão. Negrejava no burel dos santos, refulgia na espada dos heróis, palpitava no coração dos poetas. (QUEIRÓS, 2000, p. 118)

O primeiro aspecto em relação a esse intertexto é o anedótico. O segundo, seu carácter memorialístico, por isso há aí um cunho pessoal nas escolhas dos episódios que serão revisitados. Desse aspecto, desdobra-se uma certa vacuidade das escolhas, todas orientadas por uma questão individual. Embora haja essa vacuidade nas escolhas, certamente o romance mostra por meio de Ega o conhecimento científico da época:

As poucas linhas transcritas (...) indicam-se que Eça de Queirós conhecia as teorias de Kant e de Laplace (séc. XVIII) sobre a formação do sistema solar, o darwinismo (On the origins of Species by Means of natural selection, 1859, The Descent of Man, and Selection in Relation in Sex, 1871) e também, em termos gerais, a teoria anatômica (BERBERAN E SANTOS, 2013, p. 21).

Esse apego ao individual e geral será característica de um romance que contaria a ciência por expedientes menos áridos e mais casuais e anedóticos. Essa reescritura de Ega daria mais veracidade às teorias cientificistas, sempre mais abstratas e duvidosas, porque o "átomo" seria um personagem que, estando nos episódios cruciais dessas teorias, daria seu testemunho convincente e definitivo. Em solo português, a inversão dos papeis é clara: será a ficção que dará veracidade à teoria e não o contrário.

No final do romance Os Maias, temos Carlos da Maia e Ega visitando o Ramalhete, passados dez anos dos principais acontecimentos da narrativa. O desfecho é uma espécie de remate em que sabemos o destino de alguns personagens. Nesse remate, Carlos da Maia e seu amigo voltam a um lúgubre, melancólico e decadente Ramalhete:

Embaixo o jardim, bem arejado, limpo e frio na sua nudez de inverno, tinha a melancolia de um retiro esquecido, que já ninguém ama; uma ferrugem verde, de umidade, cobria os grossos membros da Vênus Citeréia; o cipreste e o cedro envelheciam juntos, como dous amigos num ermo; de mais lento corria o prantozinho da cascata, esfiado saudosamente, gota a gota, na bacia de mármore (QUEIRÓS, 2000, p. 688).

Nessa descrição, que se constitui também numa espécie de revisão da vida de Carlos, aparecerem contrabalançados sentimentos e ironias; lirismo e realidade, numa amostra perfeita da maturidade narrativa de Eça de Queirós. Assim, nem os arroubos 
MORAIS, M.P.A.; OLIVEIRA, M.F.

cientificistas de algumas narrativas, nem o espírito galhofeiro reflexo do viés crítico do autor, nem o excesso de sentimentalismo aparecem nesse final. Essa escrita equilibrada é acompanhada por uma tentativa de também encontrar um equilíbrio na vida:

Depois Carlos (...) deu a sua teoria da vida, a teoria definitiva que ele deduzira da experiência e que, agora, o governava. Era o fatalismo muçulmano. Nada desejar e nada recear... Não se abandonar a uma esperança - nem a um desapontamento. (...) $\mathrm{E}$, nesta placidez, deixar esse pedaço de matéria organizada, que se chama o Eu, ir-se deteriorando e descompondo até reentrar e se perder no infinito Universo...Sobretudo não ter apetites (QUEIRÒS, 2000, p. 693).

Como tudo em Os Maias é marcado pelo desejo/descrença, memória/esquecimento, amor/tédio e modernidade/tradição, também essa filosofia é contrariada pela realidade imediata, porque Carlos e Ega terminam o texto correndo atrás de um bonde.

A cultura portuguesa em Os Maias aparece exposta a um conjunto de imagens europeias. Eduardo Lourenço chama atenção para uma constatação geográfica, histórica e simbólica sobre Portugal, a qual ajuda a pensar sobre essa questão:

... praia que (...) incitava os marinheiros audaciosos ávidos à descoberta daquilo que o oceano desconhecido ocultava; e cais virado não apenas para o mar cruel e visível desse mundo, mas também para o Infinito e Indefinido... (LOURENÇO, 2001, p. 57-8)

Possivelmente, o debate de Eça de Queirós encaminha-nos a pensar Portugal nessa dupla observação: a de se portar como cais, fecho de si e da Europa e a de querer continuar a ser praia e empreender outras imagens, relações pluricontinentais. Nossa pequena amostragem observou o século XIX e o contato português com as ideologias europeias. Natália Correia, escritora contemporânea, aposta em outra vertente: no futuro ibérico para Portugal

Esse caminho aponta para uma comunidade cultural ibero-afro-americana. Nesta época planetária que nos instiga a tirar frutos do nosso ecumeninso, a vertente atlântica solicita um projeto pluricontinental que englobaria, pelo lado da lusofonia, Portugal, o Brasil e os países africanos de fala oficial portuguesa e, pelo outro ramo da cultura ibérica, a Espanha e as Américas espanófonas (CORREIA, 2003, p. 13). 
MORAIS, M.P.A.; OLIVEIRA, M.F.

Pelo que vimos, a obra de Eça de Queirós ainda nos oferece uma visão muito viva e pulsante sobre o passado e futuro de Portugal.

\section{CONSIDERAÇÕES FINAIS}

Discutimos, ao longo deste trabalho, como a cultura portuguesa dialoga com 0 conjunto de ideias e conceitos dos demais países hegemônicos europeus no século XIX. A obra de Eça de Queirós apresenta uma exaustiva reflexão acerca de uma recepção entusiasmada e de uma recepção crítica do modelo de vida e de cultura europeias a que Portugal está exposto.

A discussão acerca das recepções e adaptações das outras culturas europeias em território português, um olhar exterior a si que a cultura portuguesa não produzira até Eça de Queirós (LOURENÇO, 1999, p. 9) proporcionam um debate identitário complexo no início do século XX em Portugal. Como continuação desta questão, sugerimos pensar nas respostas diversas a esse debate como a empreendida na literatura por Fernando Pessoa e sua despersonalização ou José Saramago e seu iberismo.

Por ora, observamos como Portugal recusa seu iberismo e a ele faz uma escolha consciente de ser "moderno" como França, Alemanha ou Inglaterra o eram. Mas essa identificação vem, como as obras de Eça de Queirós comprovam, marcada por uma mediação efetiva e consciente do diálogo entre as culturas.

\section{REFERÊNCIAS}

ABDALA JÚNIOR e PASCHOALIN, Maria Aparecida. História Social da Literatura Portuguesa. São Paulo: Ática, 1994.

BAUDELAIRE, Charles. Sobre a modernidade. Rio de Janeiro: Paz e Terra, 1996.

BERBERAN E SANTOS, Mário. Sobre a nudez forte do núcleo, o manto diáfano da nuvem electrónica: As memórias dum Átomo. Química 130, jul-set. 2013. Disponível em: http://web.ist.utl.pt/berberan/data/As\%20Memorias\%20dum\%20Atomo.pdf. Acesso em: 15/07/2019.

CANDIDO, Antonio. Entre campo e cidade. In: Tese e antítese. 5 ed. Rio de 
MORAIS, M.P.A.; OLIVEIRA, M.F.

Janeiro: Ouro sobre o Azul, 2006.

COELHO, Jacinto do Prado. A originalidade da Literatura Portuguesa. Lisboa: Instituto de Cultura e Língua Portuguesa, 1992.

CORREIA, Natália. Somos todos hispanos. 2 ed. Lisboa: Editorial Notícias, 2003.

DUARTE, Maria do Rosário Cunha. Rejeição e recepção das ideias francesas na literatura portuguesa. Porto Alegre, Letras Hoje, v. 43, n.4, p.65-68, dez. 2008.

FALBEL, Nachman. Romantismo, Historicismo e História. In: GUINSBURG, J. 0 romantismo. São Paulo: Perspectiva, 2008

FIGUEIREDO, Mônica. "A Lisboa não é Paris: O Primo Basílio, de Eça de Queirós.” In: SCARPELI, Marli Fantini e OLIVEIRA, Paulo Motta.(orgs.). Os centenários: Eça, Freyre e Nobre. Belo Horizonte: FALE, UFMG, 2001.

GIRARD, René. Mentira romântica y verdade novelesca. Trad. Joaquín Jordá. Anagrama: Barcelona, 1985.

LOURENÇO, Eduardo. Mitologia da saudade: seguido de Portugal como destino. São Paulo: Companhia das Letras, 1999.

Companhia das Letras, 2001.

A nau de Ícaro e Imagem e miragem da lusofonia. São Paulo: . Portugal como destino seguido de Mitologia da saudade. Portugal:

Gradiva, 2012.

MEDINA, João. À margem dum ensaio de Eça de Queirós; Nótulas sobre o "Francesismo", sua cronologia e suas fontes. Colóquio Letras, no. 10, nov. 1992. Disponível em: http://coloquio.gulbenkian.pt/bib/sirius.exe/issueContentDisplay? $n=10 \& p=34 \& 0=p$ Acesso em: 25/05/2014.

QUEIRÓS, Eça. O Primo Basílio. São Paulo: Scipione, 1994.

2013.

A correspondência de Fradique Mendes. Rio de Janeiro: Best Bolso, Os Maias. Rio de Janeiro: Ediouro, 2000.

REIS, Carlos. Estudos Queirosianos; Ensaios sobre Eça de Queirós e a sua obra. Lisboa: Editorial Presença, 1999. 
ROCHA, João Cezar de Castro. Culturas shakespearianas: teoria mimética e os desafios da mímesis em circunstâncias não hegemônicas. São Paulo: É Realizações, 2017.

SANTIAGO, Silviano. "Eça, autor de Madame Bovary." In: . Uma Literatura nos trópicos; ensaios sobre dependência cultural. 2 ed. Rio de Janeiro: Rocco, 2000.

SANTOS, Boaventura de Sousa. Pela mão de Alice; o social e o político na pósmodernidade. 7 ed. Afrontamento: Porto, 1999.

SARAIVA, A. J e LOPES, Óscar. História da Literatura Portuguesa. 17 ed. Porto: Porto Editora, 1996.

Como citar este artigo (ABNT)

MORAIS, M.P.A.; OLIVEIRA, M.F. Eça de Queirós, Portugal e as relações culturais. SELL, Uberaba, MG, v. X, n. X, p. XXX-XXX, 2019. Disponível em: <inserir link de acesso . Acesso em: inserir dia, mês e ano de acesso. DOI: inserir link do DOI.

Como citar este artigo (APA)

Morais, M.P.A.; Oliveira, M.F. Eça de Queirós, Portugal e as relações culturais.SELL,

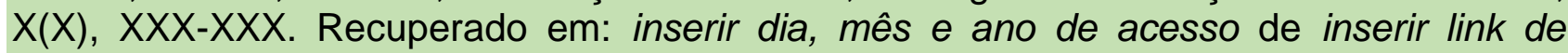
acesso. DOI: inserir link do DOI. 